\title{
At what stratigraphical level is the mid Ludfordian (Ludlow, Silurian) positive carbon isotope excursion in the type Ludlow area, Shropshire, England?
}

\author{
DAVID K. LOYDELL \& JIŘí FRÝDA
}

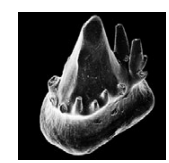

\begin{abstract}
The balance of evidence suggests that the mid Ludfordian positive carbon isotope excursion (CIE) commences in the Ludlow area, England in the uppermost Upper Whitcliffe Formation, with the excursion continuing into at least the Platyschisma Shale Member of the overlying Downton Castle Sandstone Formation. The Ludlow Bone Bed Member, at the base of the Downton Castle Sandstone Formation has previously been considered to be of Přídolí age. Conodont and thelodont evidence, however, are consistent with the mid Ludfordian age proposed here. New $\delta^{13} \mathrm{C}_{\text {org }}$ data are presented from Weir Quarry, W of Ludlow, showing a pronounced positive excursion commencing in the uppermost Upper Whitcliffe Formation, in strata with a palynologically very strong marine influence. Elsewhere in the world, the mid Ludfordian positive CIE is associated with major facies changes indicated shallowing; the lithofacies evidence from the Ludlow area is consistent with this. There appears not to be a major stratigraphical break at the base of the Ludlow Bone Bed Member. - Key words: Silurian, Ludlow, carbon isotopes, conodonts, chitinozoans, thelodonts, stratigraphy.
\end{abstract}

LOYDELL, D.K. \& FRÝDA, J. 2011. At what stratigraphical level is the mid Ludfordian (Ludlow, Silurian) positive carbon isotope excursion in the type Ludlow area, Shropshire, England? Bulletin of Geosciences 86(2), 197-208 (5 figures, 2 tables). Czech Geological Survey, Prague. ISSN 1214-1119. Manuscript received January 17, 2011; accepted in revised form March 28, 2011; published online April 13, 2011; issued June 20, 2011.

David K. Loydell, School of Earth and Environmental Sciences, University of Portsmouth, Burnaby Road, Portsmouth PO1 3QL, UK; david.loydell@port.ac.uk•Jiři Frýda, Czech Geological Survey, P.O.B. 85, 11821 Prague 1, and Faculty of Environmental Sciences, Czech University of Life Sciences Prague, Kamýcká 129, 16521 Praha 6 - Suchdol, Czech Republic; bellerophon@seznam.cz.

It is now generally recognised that the Silurian was a period of profound global environmental changes which are reflected in the geological record by extinction events, major facies changes and positive carbon isotope excursions. In this paper an attempt is made to constrain stratigraphically the mid Ludfordian (Ludlow) positive carbon isotope excursion (CIE) in Shropshire, England, on the margins of the early Palaeozoic Welsh Basin.

This mid Ludfordian positive CIE is the largest in the Phanerozoic, with $\delta^{13} \mathrm{C}_{\text {carb }}$ values exceeding $+11 \%$, recorded from Sweden, on the palaeocontinent Baltica (Wigforss-Lange 1999), and $+12-13 \%$ o from Australia (Andrew et al. 1994), part of the Gondwanan supercontinent. Given that earlier Silurian positive carbon isotope excursions have been identified in the Welsh Basin and/or on its margins (e.g. the early Sheinwoodian excursion: Loydell \& Frýda 2007, Cramer et al. 2010; the mid Homerian excursion: Corfield et al. 1992), it would seem reasonable to expect that evidence for the mid Ludfordian event should be preserved in strata in the region also. Thus far, however, it has not been recognised; indeed there are no published (or, to the authors' knowledge, unpublished) studies of the isotopic record in the Ludfordian strata of Wales and the Welsh Borderland.

The paper commences with discussions of Ludfordian biostratigraphy, both globally and in the Anglo-Welsh area in an attempt to constrain the bio- and lithostratigraphical level at which the isotope excursion should be sought. Facies changes associated with the excursion in Baltica, peri-Gondwanan Europe and Laurentia are discussed with a view to determining, from a sequence stratigraphical viewpoint, what might be expected from Shropshire's geological record at the excursion level. Having identified the two stratigraphical levels which fulfil some or all of the necessary criteria to have the potential to preserve the excursion, the results of $\delta^{13} \mathrm{C}$ analyses (for methodology see Loydell \& Frýda 2007) on samples from two carefully chosen sections are presented and discussed.

The term mid Ludfordian is preferred here to late Ludfordian (as used previously by several authors, e.g. Munnecke et al. 2003, Jeppsson 2005, Stricanne et al. 2006, Loydell 2007, Eriksson \& Calner 2008) as it more accurately reflects the stratigraphical level of the excursion, as discussed below. Kaljo \& Martma (2006), Barrick 


\begin{tabular}{|c|c|}
\hline East European Platform, Poland & Barrandian, Czech Republic \\
\hline Uncinatograptus spineus & \multirow{3}{*}{ Pristiograptus fragmentalis } \\
\hline Uncinatograptus protospineus & \\
\hline Uncinatograptus acer & \\
\hline $\begin{array}{l}\text { Pseudomonoclimacis latilobus/ } \\
\text { Slovinograptus balticus }\end{array}$ & $\begin{array}{l}\text { Pseudomonoclimacis latilobus/ } \\
\text { Slovinograptus balticus }\end{array}$ \\
\hline Neocucullograptus kozlowskii & Neocucullograptus kozlowskii \\
\hline Neocucullograptus inexpectatus & Neocucullograptus inexpectatus \\
\hline Neolobograptus auriculatus & \multirow{3}{*}{ Bohemograptus tenuis } \\
\hline Bohemograptus cornutus & \\
\hline Bohemograptus praecornutus & \\
\hline $\begin{array}{l}\text { Cucullo. aversus/ } \\
\text { S. leintwardinensis }\end{array}$ & Saetograptus linearis \\
\hline
\end{tabular}

Figure 1. Correlation of the Ludfordian graptolite biozonations of Poland and Bohemia (from Loydell in press).

et al. (2010), Slavík et al. (2010) and Manda et al. (in press) also refer to this excursion (and/or the penecontemporaneous Lau and Kozlowskii events) as mid Ludfordian.

\section{Ludfordian biostratigraphy and the mid Ludfordian positive carbon isotope excursion}

Three fossil groups are widely used in Silurian biostratigraphy: graptolites, chitinozoans and conodonts. Two other groups, ostracods and thelodonts are important in many regions; their significance in the Ludlow area is considered later in this paper when the age of the Ludlow Bone Bed Member is discussed.

\section{Ludfordian graptolite biostratigraphy and the mid Ludfordian positive carbon isotope excursion}

A remarkably detailed graptolite biozonation has been erected for the Ludfordian of the East European Platform of Poland (Baltica) with ten biozones recognised by Urbanek \& Teller (1997). In Bohemia (peri-Gondwanan Europe), fewer (six) biozones are recognised. Correlations are indicated in Fig. 1. Two major extinction events have been recognised in the Ludfordian and these have a profound impact on the nature of graptolite assemblages (Urbanek 1993, Melchin et al. 1998). By the end of the earliest Ludfordian Saetograptus leintwardinensis Zone, retiolitids, Saetograptus and Cucullograptus, all important constituents of Gorstian graptolite faunas, were extinct. Urbanek (1993) referred to this major extinction event as $C_{2}$ (crisis 2) or the leintwardinensis Event. Post-leintwardinensis Biozone graptolite assemblages are dominated by Neocucullograptus and Bohemograptus until both of these genera became extinct at the end of the Neocucullograptus kozlowskii Zone in the second of the Ludfordian graptolite crises, $\mathrm{C}_{3}$ or the kozlowskii Event.

In Kosov Quarry Bohemia, the mid Ludfordian excursion commences just above the LADs of Bohemograptus and Neocucullograptus kozlowskii (Lehnert et al. 2007) and thus the excursion coincides with the kozlowskii Event. This parallels the relationship between excursions and graptolite extinctions seen earlier in the Silurian (Loydell 2007).

\section{Graptolites in the Ludlow area}

Despite the absence of graptolites above the Upper Leintwardine Formation, they still provide an extremely useful biostratigraphical constraint upon the level at which to search for the mid Ludfordian excursion. The presence of the lower Ludfordian biozonal index graptolite Saetograptus leintwardinensis in the Lower and Upper Leintwardine formations (Holland et al. 1963) indicates clearly that the mid Ludfordian excursion, if recorded in the rock record, must lie at a higher stratigraphical level.

\section{Ludfordian chitinozoan biostratigraphy and the mid Ludfordian positive carbon isotope excursion}

Verniers et al. (1995), in their 'global Chitinozoa biozonation for the Silurian', recognised two Ludfordian biozones. The lower, Eisenackitina philipi Biozone has its base defined by the FAD of the eponymous species in the Ludlow area. The succeeding chitinozoan biozone is the E. barrandei Biozone. An unzoned interval was placed between these two biozones, reflecting the paucity of chitinozoans above the LAD of E. philipi in the Ludlow area and general lack of studies at this time elsewhere on this interval.

There is a consistent relationship between the FADs of Eisenackitina philipi and E. barrandei: in all published sections the FAD of the former occurs several tens of metres below that of the latter. Although used successfully as a biozonal index in southern Sweden (Grahn 1996), in the East Baltic region E. philipi is rare, prompting Nestor (2009) to erect an E. lagenomorpha Biozone for the lower Ludfordian. The FAD of confidently identified E. philipi in the East Baltic region is at the base of, or very low in the E. lagenomorpha Biozone (Nestor 2009), suggesting that the bases of the E. philipi and E. lagenomorpha biozones are at an approximately synchronous level. It appears that the LAD of E. philipi is at a lower stratigraphical level than that of E. lagenomorpha: this is certainly the case on Gotland (Laufeld 1974) and in the East Baltic (Nestor 2009).

The stratigraphical utility of other late Silurian chitinozoan taxa is highly variable. Urnochitina gr. urna is 
stated by Paris (in Kř́ž et al. 1986) to be 'most probably completely restricted to the Přídolí' and this is obviously therefore an important and useful species group, particularly as several studies have recorded chitinozoans through the uppermost Ludlow/lower Př́idolí transition. Sphaerochitina sphaerocephala has been consistently recorded only from the E. barrandei Biozone and higher strata and also therefore appears to be an important species, despite Laufeld's (1974) misgivings that "it is hard to escape the conclusion that $S$. sphaerocephala has become a wastebasket taxon". The level of first appearance of S. sphaerocephala is, however, difficult to assess: in several sections it is present in the lowest sample studied, e.g. the Požáry and Koledník quarries, Bohemia (Kř́ž et al. 1986), the A1-61 borehole, Libya (Jaglin \& Paris 2002) and thus may well occur in lower strata. On Gotland, from which $E$. barrandei has not been recorded, the FAD of $S$. cf. sphaerocephala at the base of the Hamra Formation is immediately above the Burgsvik Formation, a unit with an unusual chitinozoan assemblage, considered to be highly facies dependent (Laufeld 1974) and thus the absence of $S$. cf. sphaerocephala may be environmentally rather than stratigraphically controlled. The 'cf.' used by Laufeld (1974) reflects the 'atypical' appearance of the lowest Hamra Formation specimens (from unit a, which is 0.2-1.5 m thick out of a total formational thickness of $40 \mathrm{~m}$ ). S. sphaerocephala is a highly variable species (see e.g. Wrona 1980, fig. 9), so it may be that these atypical specimens can be accommodated within the species. Typical S. sphaerocephala were found by Laufeld (1974) in unit b of the Hamra Formation. Jeppsson et al. (2006) assigned the Hamra Formation to the Ozarkodina snajdri Biozone. The lower part of this formation, including unit $b$, is still within the mid Ludfordian excursion (Stricanne et al. 2006). In the Klintaborrningen 1 section, Sweden, the FAD of $S$. sphaerocephala is immediately above the LAD of E. philipi within the long stratigraphical ranges of E. lagenomorpha and Angochitina echinata; E. barrandei was not identified from this section (Grahn 1996). The available evidence, particularly that from Gotland, suggests that the stratigraphically earliest $S$. sphaerocephala appeared significantly before the first $E$. barrandei. This is important with regard to the dating of the mid Ludfordian excursion in the Ventspils D-3 core, Latvia (see below).

As knowledge of chitinozoan biostratigraphy has increased, other taxa, previously thought to be of stratigraphical importance, have been shown to have longer ranges than originally thought and these cannot therefore be used with any confidence in high resolution studies. For example, Pterochitina perivelata is part of Paris's (in Křiž et al. 1986) Př́idolí assemblage, but has recently been found by Nestor (2009) throughout much of the Ludfordian of the Pavilosta core, Latvia. Similarly, Ancyrochitina pedavis, stated to be 'restricted to the uppermost Ludlow' by Paris (in Kříž et al.
1986), occurs in both the E. lagenomorpha and E. barrandei biozones of the Pavilosta core (Nestor 2009).

\section{Chitinozoan dating of the mid Ludfordian excursion}

In the Ventspils D-3 core the mid Ludfordian excursion occurs between depths of $470 \mathrm{~m}$ and $460 \mathrm{~m}$ (Kaljo et al. 1998). According to Nestor (2009, fig. 4) this level is within the lower part of the Eisenackitina barrandei Biozone. The biozonal species, however, was not confidently identified in the core. Dating of the CIE in the Ventspils D-3 core as E. barrandei Biozone hinges on Sphaerochitina sphaerocephala, confidently identified immediately below the excursion from the $-472 \mathrm{~m}$ sample, not occurring below the $E$. barrandei Biozone. The stratigraphical significance of this species is discussed at length above and it is concluded, however, that its first appearance was most probably before that of E. barrandei. The FAD of confidently identified $E$. philipi in the Ventspils D-3 core is approximately $40 \mathrm{~m}$ below the onset of the excursion; its LAD is within the excursion interval. The isotope excursion occurs at a level (upper Mituva Formation) at which chitinozoan diversity declined markedly and in the overlying Ventspils Formation chitinozoans are 'scarce'. Nestor (2009) related the diversity decline to the Lau Event and refers to 'intense extinction of chitinozoans'. A major extinction at this stratigraphical level is not apparent from the data from the other cores (Ohesaare, Pavilosta and Dubovskoye) studied by Nestor, however, nor from her summary range chart (fig. 7) suggesting that local environmental/preservational factors are responsible for the reduced chitinozoan diversity and abundance seen in the Ventspils D-3 core.

A peak $\delta^{13} \mathrm{C}_{\text {carb }}$ value of $4.2 \%$ was recorded in the Pavilosta core, Latvia by Kaljo et al. (1998). This was at a depth of 739 m (Kaljo \& Martma pers. comm., December 2010), within the lower half of the Eisenackitina lagenomorpha Biozone and $44 \mathrm{~m}$ below the FAD of Eisenackitina barrandei.

In both cores (Ventspils D-3 and Pavilosta) the excursion occurs significantly above the FAD of Eisenackitina philipi. The LAD of E. philipi lies $3 \mathrm{~m}$ below the peak $\delta^{13} C_{\text {carb }}$ value in Pavilosta and within the excursion interval in the Ventspils D-3 core. On Gotland the LAD of E. philipi also lies within the excursion, in the Burgsvik Formation (Laufeld 1974).

Isotope and chitinozoan data are available also from the Czech Republic. In the section close to the tunnel entrance at Požáry Quarry the mid Ludfordian CIE has been recorded in beds 34-41 (Lehnert et al. 2007). Eisenackitina barrandei was recorded by Paris \& Kříž (1984) from beds 87-96 (highest Ludlow to lowermost Přídolí; note that beds below bed 87 were not studied). Bed 87 is more than 
$10 \mathrm{~m}$ above the excursion. This indicates that the excursion is not within the upper part of the E. barrandei Biozone and indeed need not lie within this biozone at all.

\section{Chitinozoans in the Ludlow area}

A thorough review of the Ludlow chitinozoans of the Ludlow area was provided by Sutherland (1994). As noted above, the base of the E. philipi Biozone was defined in the Ludlow area (Verniers et al. 1995). The biozone here encompasses the upper part of the Upper Leintwardine Formation, the entire Lower Whitcliffe Formation and lower part of the Upper Whitcliffe Formation. Above this level chitinozoans are rare, but still present in the upper part of the Upper Whitcliffe Formation (Richardson \& Rasul 1990). Sutherland (1994) explained this by suggesting that during the Ludfordian increased input of fresh water dramatically reduced the numbers of chitinozoan producers living in the shelf seas surrounding the Welsh Basin.

Richardson \& Rasul (1990, fig. 10b) illustrated a chitinozoan, identified as E. barrandei Paris \& Kř́ǐ̌, 1984 by Florentin Paris, from their sample $16 \mathrm{~J}$ in the Upper Whitcliffe Formation. This sample is from $0.23-0.26 \mathrm{~m}$ below the base of the Ludlow Bone Bed Member of the Downton Castle Sandstone Formation at Weir Quarry, near Downton ca $5 \mathrm{~km} \mathrm{~W}$ of Ludlow. The identification of E. barrandei was accepted by Verniers et al. (1995) in their global biozonation paper. Miller et al. (1997) subsequently erected new chitinozoan species from Nantyrhynau Quarry, eastern Wales, more than $30 \mathrm{~km}$ WNW of Weir Quarry, in deeper water, turbiditic strata, considered to straddle the Ludlow/Př́idolí series boundary and be the lateral equivalent of the upper part of the Upper Whitcliffe Formation and lower Downton Castle Sandstone Formation. One of their new species, Eisenackitina clunensis, is very similar to $E$. barrandei, differing only in the position of vesicle flexure. In E. clunensis this occurs at a mid-point on the vesicle flanks, whereas in E. barrande $i$ the flexure is closer to the aperture (Miller et al. 1997). This difference becomes significant now that Nestor has recorded all of Miller et al.'s (1997) new species from the East Baltic region and shown that all of them here have different or longer stratigraphical ranges than seen in Nantyrhynau Quarry. Of particular significance is the occurrence of E. clunensis in the upper Angochitina elongata and lower Eisenackitina lagenomorpha biozones, with a LAD below that of E. philipi. In combination with the Welsh data, this indicates that this species has a long stratigraphical range, and probably it cannot be used in high resolution biostratigraphy. Why is this significant? In Richardson \& Rasul's (1990) specimen from the Upper Whitcliffe Formation of Weir Quarry the location of flexure suggests that this specimen is not in fact E. barrandei, but instead is
E. clunensis. Thus the Upper Whitcliffe Formation/Downton Castle Sandstone Formation boundary need not be at a stratigraphical level above the base of the E. barrandei Biozone (i.e. uppermost Ludfordian).

\section{Ludfordian conodont biostratigraphy and the mid Ludfordian positive carbon isotope excursion}

Although Corradini (2009) emphasized that much work remains to be done before there is a widely accepted upper Silurian 'Standard Conodont Zonation', all six of the conodont biozonations for the Ludfordian presented were united in having the lower Ludfordian Ancoradella ploeckensis Biozone succeeded by a Polygnathoides siluricus Biozone. Similarly, all six terminated the Ludfordian Stage with the Ozarkodina crispa Biozone. The greatest variation lay between the siluricus and crispa biozones with $\mathrm{Pe}$ davis latialata and/or O. snajdri biozones recognised. Jeppsson (2005) erected an Icriodontid Biozone for this interval. Conodont occurrence data provided by various authors (e.g. Miller 1995, Koren' \& Walliser 1998, Viira \& Aldridge 1998, Corradini \& Serpagli 1999) indicate that conodont dating and correlation of Ludfordian strata may not, however, be as straightforward as published charts of conodont biozones might imply.

In this respect, it is interesting to compare the chitinozoan data of Nestor (2009) for the Ohesaare core, Saaremaa (Estonia) with the conodont biozonation of Viira $\&$ Aldridge (1998, fig. 6). Here the O. crispa Biozone is recognised from $-95.95 \mathrm{~m}$ to $-101.05 \mathrm{~m}$. According to all of the biozonations shown by Corradini (2009), the O. crispa Biozone is the highest in the Ludfordian, yet the chitinozoans within the stratigraphical range of $O$. crispa in the Ohesaare core indicate the uppermost Angochitina elongata and lower Eisenackitina lagenomorpha biozones, not the upper Ludfordian Eisenackitina barrandei Biozone. The highest Ludfordian conodont biozone in the Ohesaare core is the Ozarkodina parasnajdri Biozone. Lithostratigraphical and thelodont evidence also point to a stratigraphical level for the Saaremaa O. crispa substantially lower than the upper Ludfordian (possibly even upper Gorstian). Viira \& Aldridge (1998, p. 48) concluded that: "An explanation may be that the fluctuating nearshore environment of Saaremaa was suited to the earlier evolution of populations of $O$. crispa."

Viira \& Aldridge (1998) distinguished three morphs of Ozarkodina crispa. The stratigraphically early specimens from Ohesaare (and several other cores and outcrops) belong to morphs $\alpha_{2}$ and $\alpha_{3}$. The stratigraphical significance of morph $\alpha_{3}$ in the Ludlow area is discussed below.

Jeppsson's (2005) revision of the Ludfordian conodont biostratigraphy for Gotland enables the isotope excursion 
here to be dated precisely: the excursion commences in the uppermost part of the $P$. siluricus Biozone; high values continue through the Icriodontid Biozone and much of the $O$. snajdri Biozone; they decline towards the top of the $O$. snajdri Biozone (Stricanne et al. 2006, fig. 3). Kaljo \& Martma (2006) showed the relationship of the mid Ludfordian excursion to biostratigraphical data from several fossil groups. For the Vidukle and Ventspils cores, the pattern is consistent with that on Gotland, with the LAD of $P$. siluricus just below the excursion. In Ventspils, $O$. snajdri occurs within the excursion interval (Kaljo \& Martma 2006, fig. 4), but as this species has a long stratigraphical range (appearing in the lower Gorstian; Jeppsson 2005 , p. 276), the stratigraphical significance of this occurrence is limited.

In Bohemia (peri-Gondwanan Europe) the beginning of the excursion has also been dated to the $P$. siluricus Biozone (Lehnert et al. 2007, Slavík et al. 2010) as it has also in the United States (Barrick et al. 2010). In the latter no Icriodontid Biozone was recognizable.

\section{Conodonts in the Ludlow area}

Miller (1995) recorded conodonts identified as $O$. cf. crispa from the Upper Whitcliffe Formation 0.3-0.15 m below the Ludlow Bone Bed Member at Ludford Corner, Ludlow. Viira \& Aldridge (1998, p. 48) identified these as their morph $\alpha_{3}$. Miller (1995, p. 374) used the presence of $O$. cf. crispa in the uppermost Upper Whitcliffe Formation at Ludford Corner as evidence that the "base of the Přídolí Series in Britain is very close to the level of the base of the Downton Castle Sandstone Formation". The identification of the material by Viira \& Aldridge (1998) as their morph $\alpha_{3}$ and the stratigraphical level at which this morph occurs on Estonia suggest that the uppermost Upper Whitcliffe Formation in Ludlow could be considerably older than latest Ludfordian. The significance of this is discussed below.

Jeppsson \& Aldridge (2000), whilst noting that in the Ludlow area "conodont information is sparse", suggested that the Lau Event (a conodont extinction event stratigraphically within the mid Ludfordian positive CIE on Gotland) "is probably represented close to the boundary between the Upper Leintwardine Formation and the Lower Whitcliffe Formation".

\section{Facies changes and unconformities associated with the mid Ludfordian positive carbon isotope excursion}

The mid Ludfordian positive CIE is associated with major facies changes indicating shallowing and/or with a stratigraphical break. This shallowing is reflected in Johnson's

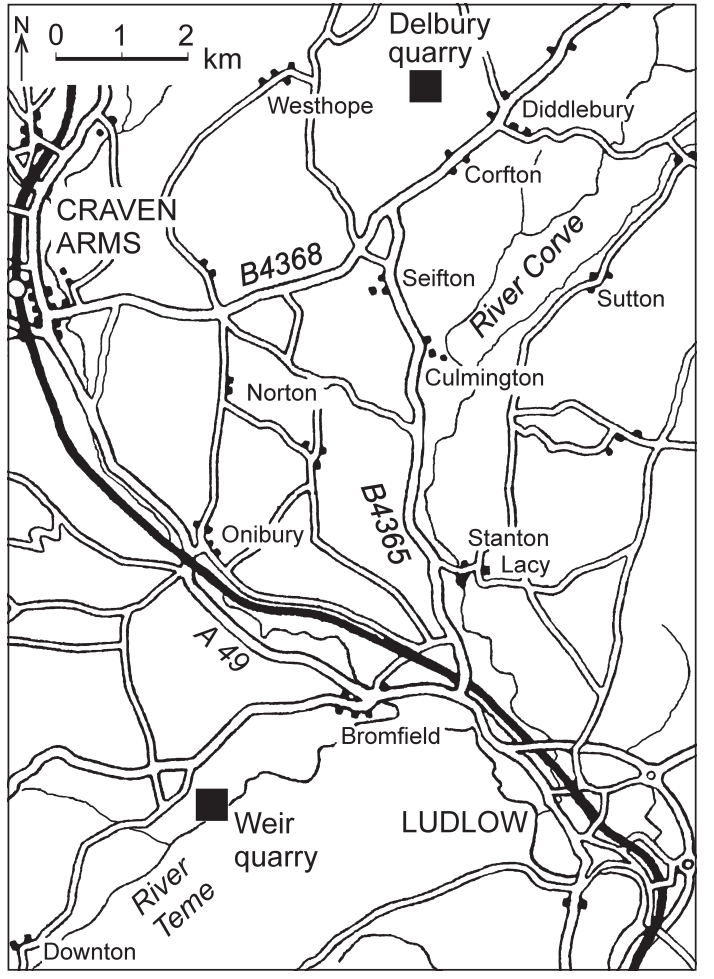

Figure 2. Map of Ludlow area showing location of Weir and Delbury quarries.

(1996) eustatic sea-level curve for the Silurian where an interval of low sea-level is shown in the mid Ludfordian (between highstands 7 and 8).

Not surprisingly, facies changes indicating shallowing have been recorded from many sections worldwide. On western Gotland (Baltica) the excursion commences close to the boundary between the Hemse Group (distal shelf mudstones with graptolites) and the Eke Formation (which includes proximal shelf oncolitic limestones) (Jeppsson 2005, Stricanne et al. 2006; see Eriksson \& Calner 2008 for a more detailed facies analysis). At this stratigraphical level on eastern Gotland, Cherns (1982) recognised palaeokarsts indicating emergence; Jeppsson (2005), Jeppsson et al. (2007) and Eriksson \& Calner (2008) also recognised a 'brief hiatus' at this level. A very similar shallowing trend to that on Gotland, from marls to oncoidal limestones, was recorded from Australia (Gondwana) by Jeppsson et al. (2007).

In Kosov Quarry, Bohemia (peri-Gondwanan Europe), graptolitic strata below the CIE indicating a 'deeper and less oxygenated' environment are overlain by shallower marine, thicker bedded limestones, in which the excursion is recorded (Lehnert et al. 2007); in Požáry Quarry, Bohemia the excursion occurs in strata exhibiting 'rapid shallowing' with massive limestone beds with palaeokarst development (Lehnert et al. 2007); a gap in the conodont record has recently been recognised at this level (Slavík et al. 2010). Palaeokarst development at the same 
Table 1. $\delta^{13} \mathrm{C}_{\mathrm{carb}}$ and $\delta^{18} \mathrm{O}$ data for Delbury Quarry. Measurements (in metres) for sampling levels are taken from the base of the Lower Whitcliffe Formation.

\begin{tabular}{ccr}
\hline Sample & $\delta^{13} \mathrm{C}_{\mathrm{carb}}$ & \multicolumn{1}{c}{$\delta^{18} \mathrm{O}$} \\
\hline+4.0 & -0.06 & -10.55 \\
+3.8 & +0.02 & -10.08 \\
+3.6 & -0.09 & -9.97 \\
+3.4 & +0.15 & -8.57 \\
+3.2 & +0.04 & -9.17 \\
+3.0 & -0.04 & -9.92 \\
+2.8 & -0.10 & -9.87 \\
+2.6 & -0.21 & -9.90 \\
+2.4 & -0.11 & -9.37 \\
+2.2 & -0.45 & -10.02 \\
+2.0 & -0.59 & -9.57 \\
+1.8 & -0.16 & -9.75 \\
+1.6 & -0.15 & -9.76 \\
+1.4 & -0.14 & -10.34 \\
+1.2 & -0.16 & -10.38 \\
+1.0 & -0.24 & -10.15 \\
\hline
\end{tabular}

\begin{tabular}{ccc}
\hline Sample & $\delta^{13} \mathrm{C}_{\text {carb }}$ & $\delta^{18} \mathrm{O}$ \\
\hline+0.8 & -0.58 & -9.92 \\
+0.6 & -0.39 & -9.52 \\
+0.4 & -0.16 & -9.52 \\
+0.2 & -0.11 & -10.07 \\
0 & +0.02 & -8.80 \\
-0.2 & +0.11 & -10.25 \\
-0.4 & +0.30 & -8.81 \\
-0.6 & +0.01 & -7.93 \\
-0.8 & +0.03 & -9.95 \\
-1.0 & -0.02 & -10.16 \\
-1.2 & -0.13 & -9.86 \\
-1.4 & -0.18 & -7.31 \\
-1.6 & +0.04 & -10.02 \\
-1.8 & -0.13 & -7.77 \\
-2.0 & -0.06 & -7.27 \\
\hline
\end{tabular}

stratigraphical level was also recorded from Mušlovka Quarry by Lehnert et al. (2007). The Požáry and Mušlovka sections both record the CIE, albeit incompletely. In the Ohesaare core, Estonia (Baltica), however, the stratigraphical break within the Ludfordian appears to be of greater duration and thus no major positive isotope excursion is recorded (Kaljo et al. 1997).

It is noteworthy that in the Bohemian and Baltic sections the extent of stratigraphical break is not substantial: in all cases sedimentation resumed within the Ludfordian, with several metres or tens of metres of strata before the base of the Přídolí Series is reached. Even in the Ohesaare core, where the hiatus is of greater duration and the excursion is not recorded, strata both above and below the hiatus are still within the same chitinozoan biozone (Eisenackitina lagenomorpha Biozone), although this is much reduced in thickness by comparison with the other East Baltic cores studied by Nestor (2009). From a conodont biostratigraphical viewpoint, the level of the stratigraphical gap in the Ohesaare core is interesting: it occurs between the Paadla and Kuressaare regional stages (Jeppsson et al. 1994, fig. 3), immediately above the stratigraphically early occurrences of Ozarkodina crispa (morphs $\alpha_{2}$ and $\alpha_{3}$ of Viira \& Aldridge 1998) discussed above.

Barrick et al. (2010) have recently presented data from sections in the central United States (Laurentia). In Oklahoma the greater part of the CIE is missing because of a hiatus. In Tennessee, within the Brownport Formation, the upward-coarsening Beech River Member (which underlies the CIE) is characterized in the Linden section by shale, carbonate mudstone and wackestone that grades into packstone. The CIE is developed in the overlying "Bob Member" at the base of which is a $1.35 \mathrm{~m}$ thick bed of coarse-grained grainstone. At other unspecified localities the "Bob Member" is stated by Barrick et al. (2010) to include oolitic layers and coated grains. Very similar lithological changes to those at Linden are documented for the Eagle Creek section, Tennessee. All of these lithofacies changes are clearly indicative of regression.

\section{Where is the mid Ludfordian carbon isotope excursion in the Ludlow area?}

Based on the above stratigraphical and facies observations, one would expect the mid Ludfordian positive CIE in the Ludlow area succession to be present above the LAD of $S$. leintwardinensis (in the Upper Leintwardine Formation) and be marked by a major facies change and/or a stratigraphical break. Within the Ludlow area such a facies change occurs at one level only, between the Upper Whitcliffe Formation and Downton Castle Sandstone Formation, the base of which is marked by the Ludlow Bone Bed Member. It has been suggested previously, however, that the CIE may lie close to the Upper Leintwardine Formation/Lower Whitcliffe Formation boundary, so this stratigraphical transition is discussed first.

\section{The Upper Leintwardine Formation/Lower Whitcliffe Formation boundary}

As noted above, Jeppson \& Aldridge (2000) suggested that the Lau Event (a conodont extinction event stratigraphically close to the mid Ludfordian positive CIE) "is probably represented close to the boundary between the Upper Leintwardine Formation and the Lower Whitcliffe Formation".

To see whether the excursion could be recognised at this level, samples were collected through the uppermost $2 \mathrm{~m}$ of the Upper Leintwardine Formation (nodular calcareous siltstones) and lowermost $4 \mathrm{~m}$ of the Lower Whitcliffe Formation (calcareous siltstones) from newly quarried sections at Delbury, Shropshire (SJ 494 862; see Fig. 2 for location). $\delta^{13} \mathrm{C}_{\text {carb }}$ analyses indicate that no major positive CIE is present within this stratigraphical interval (Fig. 3). The oxygen isotope data (Table 1) indicate a diagenetic influence on the results, but, despite this, the carbon results should display some evidence for a CIE of the magnitude of the mid Ludfordian excursion were it to be present. Isotope data from many other Silurian sections exhibit very low oxygen values (below $-10 \%$ ), indicative of diagenetic modification of the oxygen isotope record, but preserve a largely unmodified carbon isotope signal (see e.g. data 
presented in Andrew et al. 1994, Wigforss-Lange 1999, Cramer et al. 2006) with excursions clearly recognizable. One might argue that it is possible that there is no CIE in this interval due to isolation of the Welsh Basin resulting from progressive closure of the Iapetus Ocean (as suggested by Woodcock et al. 1988, Smith \& Ainsworth 1989). However, this is unlikely because these strata (and those overlying them) contain geographically widespread conodont, thelodont and chitinozoan taxa (e.g. Miller 1995, Miller et al. 1997, Miller \& Märss 1999), suggesting good connections with the open ocean.

Chitinozoan biostratigraphy indicates that this is not the level to look for the mid Ludfordian positive CIE anyway. The Upper Leintwardine Formation/Lower Whitcliffe Formation boundary is low within the Eisenackitina philipi Biozone. As noted above, where dated with chitinozoans the excursion is just above or includes the LAD of E. philipi.

\section{The Upper Whitcliffe Formation/Downton Castle Sandstone Formation boundary}

The base of the Downton Castle Sandstone Formation is marked by the Ludlow Bone Bed Member. This is succeeded by the Platyschisma Shale Member which in turn is overlain by the Sandstone Member.

Richardson \& Rasul (1990) conducted a detailed palynofacies analysis through the Upper Whitcliffe Formation and lower Downton Castle Sandstone Formation at Weir Quarry, Downton (SO 45607525). For this reason, this locality was chosen for sampling for isotopic analysis as comparison of isotope results would be possible with both lithological and palynological changes. The very low carbonate content and dolomitization precluded meaningful analysis of $\delta^{13} \mathrm{C}_{\text {carb }}$ from the samples; the presence of well preserved organic matter, however, enabled analysis of $\delta^{13} \mathrm{C}_{\mathrm{org}}$, the resulting curve being presented in Fig. 4 .

The $\delta^{13} \mathrm{C}_{\text {org }}$ curve clearly shows the commencement of a major positive excursion in the uppermost part of the Upper Whitcliffe Formation, with the highest $\delta^{13} \mathrm{C}_{\text {org }}$ value of $-23.88 \%$ occurring $0.78 \mathrm{~m}$ above the base of the Ludlow Bone Bed Member, within the Platyschisma Shale Member.

Comparison with Richardson \& Rasul's (1990) results is very interesting. The excursion commences in strata which, from a palynological perspective, are fully marine. Richardson \& Rasul (1990) introduced a marine influence index (in which $0=$ fully terrestrial and $100=$ fully marine) based upon the composition of palynological assemblages. Samples from 19-25.5 cm and 0-5 cm below the Ludlow Bone Bed have a marine influence index of 96.5 and 97.5 respectively. A major change in palynofacies occurs at the base of the Ludlow Bone Bed Member exemplified by the increase in percentage of spores within the assemblages, from $2.5 \%$ in the highest Upper Whitcliffe Formation sam-

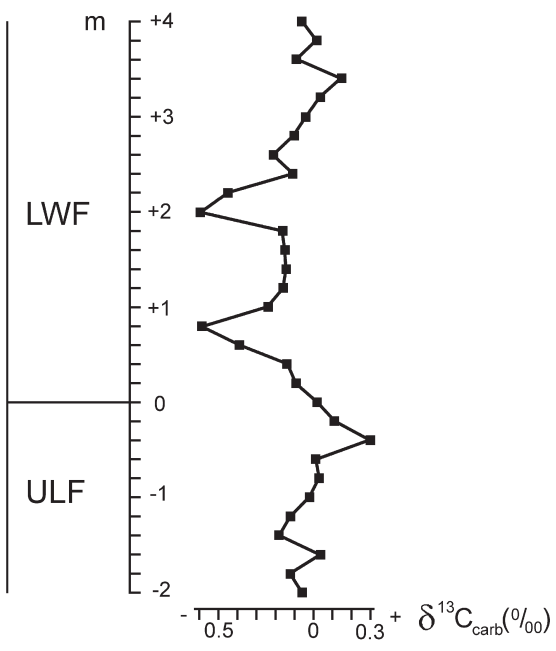

Figure 3. $\delta^{13} \mathrm{C}_{\text {carb }}$ curve (from data in Table 1) through the Upper Leintwardine/Lower Whitcliffe Formation boundary at Delbury Quarry, Shropshire. Abbreviations: ULF $=$ Upper Leintwardine Formation; LWF $=$ Lower Whitcliffe Formation. Note the scale used for the carbon isotope data. Lithologies are shown on Fig. 4. The $0 \mathrm{~m}$ sample was collected from the top of the Upper Leintwardine Formation. No major excursion is present.

Table 2. $\delta^{13} \mathrm{C}_{\text {org }}$ data for Weir Quarry. Measurements (in metres) for sampling levels are taken from the base of the Ludlow Bone Bed Member.

\begin{tabular}{ccccc}
\hline Sample & $\delta^{13} \mathrm{C}_{\text {org }}$ & & Sample & $\delta^{13} \mathrm{C}_{\text {org }}$ \\
\cline { 5 - 5 }+1.28 & -24.18 & & $-0.25-0.26$ & -26.82 \\
+1.03 & -24.39 & & -0.60 & -27.09 \\
+0.78 & -23.88 & & -0.75 & -27.04 \\
+0.53 & -24.96 & & -1.00 & -27.15 \\
+0.28 & -24.13 & & -1.10 & -26.61 \\
$+0.15-0.19$ & -25.08 & & -1.50 & -27.35 \\
$+0.15-0.19$ (repeat) & -25.14 & & -1.50 (repeat) & -27.54 \\
$+0.05-0.07$ & -25.72 & & -1.75 & -26.28 \\
$+0.05-0.07$ (repeat) & -25.66 & & -2.25 & -26.31 \\
-0.03 & -26.12 & & -2.25 (repeat) & -26.48 \\
\hline
\end{tabular}

ple to $50.5-81.5 \%$ in the $20-30 \mathrm{~mm}$ thick Ludlow Bone Bed itself. The $\delta^{13} \mathrm{C}_{\text {org }}$ values show a rapid increase through the Ludlow Bone Bed Member and lowermost Platyschisma Shale Member, reaching $-24.13 \%$ $5 \mathrm{~cm}$ above the base of the latter. The major part of the rising limb of this $\delta^{13} \mathrm{C}_{\text {org }}$ excursion is therefore within strata with a relatively consistent palynological signal, with spores dominant (values are between $50.5 \%$ and $81.5 \%$ throughout; Richardon \& Rasul 1990, table 2) with the accompanying acritarchs predominantly sphaeromorphs and Micrhystridium.

It is rather surprising that the major change in palynofacies is not the level at which the $\delta^{13} \mathrm{C}_{\text {org }}$ values show their greatest change, given that that the organic-walled palynomorphs might be expected to give a good indication 


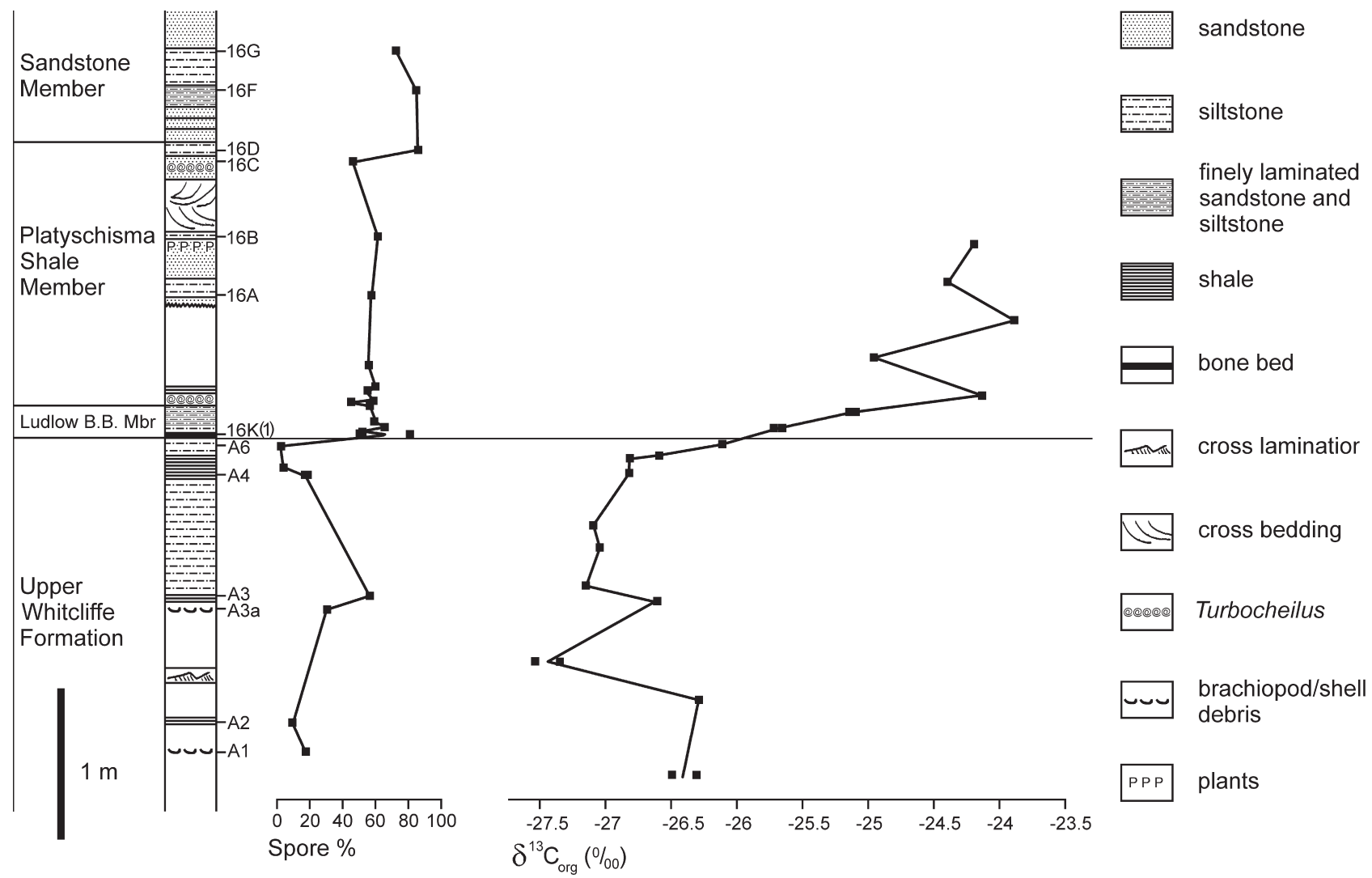

Figure 4. Percentage spore abundance and $\delta^{13} \mathrm{C}_{\text {org }}$ curves through the Upper Whitcliffe Formation and Lower Downton Castle Sandstone Formation exposed at Weir Quarry (SO 45607525). Log is modified from Richardson \& Rasul (1990, figs 2, 3), using their sample numbers (16G, A6, etc.). Additional data points (for spore \%) are from Richardson \& Rasul (1990, tab. 2). $\delta^{13} \mathrm{C}_{\mathrm{org}}$ data is that from Table 2. Where two analyses (palynological or isotope) were conducted upon the same stratigraphical interval, both points are plotted. Abbreviation: B. B. = Bone Bed.

of the organic content of the sample as a whole. It is also important to note that in the lower Downton Castle Sandstone Formation the excursion is developed in marine strata, albeit with a significant terrestrial influx of palynomorphs. Richardson \& Rasul's (1990) marine influence index for the lower part of the Platyschisma Shale Member (for which the $\delta^{13} \mathrm{C}_{\text {org }}$ data are plotted in Fig. 4) is 34.2 to 42.5 (in unreworked samples).

Stricanne et al. (2006) recorded in detail the changes in palynomorph assemblages through the Ludfordian excursion interval on western Gotland. Perhaps not surprisingly, given that in both the Ludlow area and on Gotland (as elsewhere) the excursion is developed during a major regression, the Gotland palynological signal is similar to that at Weir Quarry: spores increase in both absolute and relative abundance.

In other Silurian sections studied for both $\delta^{13} \mathrm{C}_{\text {org }}$ and $\delta^{13} \mathrm{C}_{\text {carb }}$, whilst these may provide differing signals for individual samples, major excursions are clearly identified in both sets of data: e.g. the sedgwickii Zone (late Aeronian, Llandovery) excursion in Arctic Canada (Melchin \& Holmden 2006); early Sheinwoodian excursion in Wales (Loydell \& Frýda 2007, Cramer et al. 2010) and early
Sheinwoodian and mid Homerian excursions in Arctic Canada (Noble et al. 2005).

Based on biostratigraphy, facies changes and sea-level changes, the most likely level for the beginning of the mid Ludfordian excursion is therefore high in the Upper Whitcliffe Formation with it continuing through at least the lower part of the Downton Castle Sandstone Formation. Several key questions then emerge. Firstly, is the $\delta^{13} \mathrm{C}_{\mathrm{org}}$ signal at Weir Quarry the local manifestation of this major mid Ludfordian excursion or is it simply reflecting a change in the source of organic material, with an increase in terrestrial input resulting from shallowing? If the latter, then why does the major positive shift in carbon isotope values not occur at the level when spore abundance increases twenty-fold?

Secondly, is there a significant stratigraphical gap between the Upper Whitcliffe Formation and the Ludlow Bone Bed Member? If yes, then all or part of the mid Ludfordian excursion may not be preserved at all in strata in the Ludlow area. If there is not a significant gap, which would be suggested by comparison with sedimentation patterns in the Czech Republic and the Baltic region, then is the Ludlow Bone Bed Member of Ludfordian age rather 
than of Přídolí age as it is generally portrayed? Some of these questions are discussed further below.

\section{What age is the Ludlow Bone Bed Member?}

In the absence of graptolites and chitinozoans and with conodonts very rare, fragmentary and abraded, making identification difficult (Miller 1995), other fossil groups must be used for dating the Ludlow Bone Bed Member (and overlying members of the Downton Castle Sandstone Formation). Ostracods and thelodonts both occur in the Downton Castle Sandstone Formation: the dates that they provide, however, are different and, in the light of the above observations regarding the chitinozoan and conodonts from the uppermost Upper Whitcliffe Formation and the lithological signature of the mid Ludfordian excursion in other regions and short duration of any stratigraphical breaks identified, detailed discussion of the ostracod and thelodont results is warranted here.

\section{Ostracod evidence}

The ostracods from the Ludlow Bone Bed Member indicate a Př́idolí age (Miller 1995). This age has been widely accepted and a basal Přídolí age for the Ludlow Bone Bed Member is shown in the vast majority of (if not all) recent publications on the Silurian System.

The key ostracod species is Frostiella groenvalliana which has been confidently identified only from Přídolí age strata, from many locations particularly in the Baltic Region. As Miller (1995) noted, $F$. groenvalliana has been reported from a wide range of environments and its stratigraphical distribution is 'remarkably consistent' throughout its geographical range. Miller (1995, p. 369) concluded: "Because of its apparently wide facies tolerance, the sudden appearance of $F$. groenvalliana at the base of the Ludlow Bone Bed Member is therefore unlikely to be influenced entirely by a marked facies change at that level."

\section{Thelodont evidence}

Märss \& Miller (2004) provide a very useful summary of thelodont occurrences in the Welsh Borderland which enables correlation with Baltic sections. The Lower Leintwardine Formation contains Paralogania kaarmisensis and Phlebolepis elegans. These taxa co-occur in the Himmiste Beds of the Paadla Regional Stage in Estonia. The earliest Ludfordian graptolite Saetograptus leintwardinensis occurs in the Lower Leintwardine Formation, and the Himmiste Beds are of a similar early Ludfordian age (Jeppsson et al. 1994, fig. 3). Thelodus parvidens has its FAD in the Welsh Borderland in the Whitcliffe Group; in Estonia its FAD is in the Uduvere Beds of the Paadla Regional Stage. These beds lie below the stratigraphical break between the Paadla and Kuressaare Regional Stages on Saaremaa. This is the stratigraphical break discussed above, at the level of the mid Ludfordian excursion. Finally, Märss \& Miller (2004) discuss Paralogania ludlowiensis which they state is restricted to the Downton Castle Sandstone Formation in the Welsh Borderland (Fig. 5). Miller \& Märss (1999) list occurrence data for this species on Gotland and in the East Baltic: in the Ohesaare core, Estonia, Pa. ludlowiensis occurs in the lower Kuressaare Formation, of undisputed Ludfordian age, within the Eisenackitina lagenomorpha Biozone (Nestor 2009); in the Ventspils D-3 core, Latvia $\mathrm{Pa}$. ludlowiensis occurs in the upper Mituva Formation, at a level within the mid Ludfordian excursion; likewise, on Gotland it occurs in the Eke Formation within the mid Ludfordian excursion. Lithuanian occurrences of $\mathrm{Pa}$. ludlowiensis are from higher stratigraphical levels, but are still of Ludfordian age. There are no Přídolí occurrences of $P a$. ludlowiensis in the Baltic area.

Based on the presence of the thelodont Paralogonia ludlowiensis not only in the Ludlow Bone Bed Member but also in the Sandstone Member of the Downton Castle Sandstone Formation and the stratigraphical occurrences of this species in Estonia and Latvia, the lower part at least of the Downton Castle Sandstone Formation is probably of mid Ludfordian age.

\section{Reconciling the evidence}

Clearly there is a problem with the biostratigraphical dating of the Ludlow Bone Bed Member. The ostracods, particularly Frostiella groenvalliana, indicate a Př́dolí age, whilst the thelodonts (Paralogania ludlowiensis) indicate the Ludfordian. How can this anomaly be explained? Viira \& Aldridge (1998) explained the apparently early stratigraphically records of Ozarkodina crispa in the Baltic region by suggesting that the species evolved here and later migrated into the Welsh Basin, where it is found in the uppermost part of the Upper Whitcliffe Formation. Presumably a similar explanation is required for the 'early' occurrences of Paralogania ludlowiensis in the Baltic region. Why could it not be that instead Frostiella groenvalliana evolved in the relatively restricted Welsh Basin in the Ludfordian and then spread to other regions in the Přídolí? Both scenarios are equally valid and are supported by extensive data: for example Viira \& Aldridge (1998) recorded O. crispa in the middle Ludfordian Paadla Regional Stage from a total of 23 separate samples from five different cores and four further outcrop localities.

The ostracod dating requires the mid Ludfordian excursion and associated major facies change to occur between 


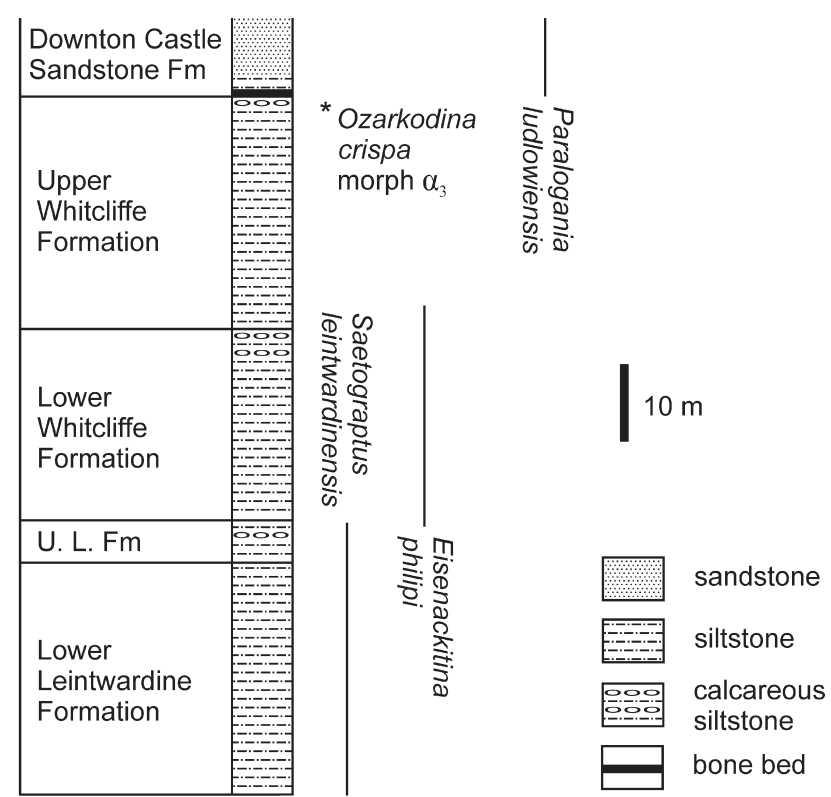

Figure 5. Summary stratigraphy of the Ludfordian of the Ludlow area, with key stratigraphical ranges/occurrences of taxa indicated. Lithologies taken from Siveter et al. 1989, fig. 30). Note that the stratigraphical range of Saetograptus leintwardinensis is as shown in Holland et al. (1963): the species may not range from the base of the Lower Leintwardine Formation to the top of the Upper Leintwardine Formation, but does occur in both formations. Note also that the LAD of Eisenackitina philipi is at a level at which chitinozoans become extremely sparse in the Ludlow area. Abbreviation: U. L. = Upper Leintwardine.

the Saetograptus leintwardinensis-bearing beds in the Upper Leintwardine Formation and the Ludlow Bone Bed Member. The only candidate level, the Upper Leintwardine/Lower Whitcliffe Formation transition, has no associated isotope excursion and chitinozoan data suggest that this is too low a stratigraphical level from a biostratigraphical perspective anyway (elsewhere the LAD of Eisenackitini philipi occurs just below or within the excursion; in the Ludlow area the base of the Lower Whitcliffe Formation is within the lower part of this species' stratigraphical range; Sutherland 1994).

The major facies change at the Upper Whitcliffe Formation/Ludlow Bone Bed Member boundary and associated $\delta^{13} \mathrm{C}_{\text {org }}$ excursion suggest that the Ludfordian date, provided by correlation with the Paadla Regional Stage of the Baltic region based upon the conodont Ozarkodina crispa morph $\alpha_{3}$ from the uppermost Upper Whitcliffe Formation and the thelodont Paralogania ludlowiensis from the Ludlow Bone Bed Member, is much more likely to be correct. It is therefore concluded here that both the Upper Whitcliffe Formation and (at least the lower part of) the Downton Castle Sandstone Formation are of mid Ludfordian age and that the marked lithological change recorded at the formational boundary is the local manifestation of the major global environmental changes associated with the mid Ludfordian isotope excursion.
A similar conclusion regarding the age of the Upper Whitcliffe Formation/Ludlow Bone Bed Member boundary has been reached previously (e.g. Schönlaub in Kř́rž et al. 1986, Aldridge \& Schönlaub 1989), prior to publication of much of the evidence presented above and the widespread acceptance of the ostracod dating of the Ludlow Bone Bed Member as Přídolí.

\section{Is there a major stratigraphical break between the Upper Whitcliffe Formation and the Ludlow Bone Bed Member?}

The base of the Ludlow Bone Bed Member marks an abrupt lithological change from the underlying Upper Whitcliffe Formation. Palynofacies also change markedly at this level (Richardson \& Rasul 1990). Almost certainly there was an interval of non-deposition and/or erosion at the boundary between the two formations: there has been some debate as to how much time this interval represents.

Bassett et al. (1982) concluded that there was "no evidence of a measurable time break" between the Upper Whitcliffe Formation and Ludlow Bone Bed Member. This was based on the "continuity of marine deposition across the boundary", the sedimentological evidence suggesting "merely slow or locally interrupted deposition" and the fact that the "ranges of numerous species of shelly macrofossils, thelodonts, ostracodes, conodonts, miospores and chitinozoans span the boundary" (although subsequent work has indicated otherwise for some groups). Further support for the likely short duration of any stratigraphical break beneath the Ludlow Bone Bed Member comes from the nature of stratigraphical breaks in other sections recording the mid Ludfordian excursion. In all cases, as discussed above, the breaks are of very limited stratigraphical extent, with even the most substantial break, at Ohesaare, Estonia, being contained within part of a single chitinozoan biozone.

A longer stratigraphical break was proposed by Viira \& Aldridge (1998) in an attempt to explain the apparently anomalous conodont records of the East Baltic region when compared with the Welsh Borderland. As indicated above there is an alternative explanation for these anomalous conodont records which does not require a significant stratigraphical break in the Ludlow area succession. Also the carbon isotope curve derived from the closely spaced samples through the Upper Whitcliffe Formation/Ludlow Bone Bed Member transition does not show any marked inflection at the formational boundary, as might be expected if there was a significant stratigraphical break at this level. We are therefore in agreement with Bassett et al. (1982) in considering that any stratigraphical break at this level represents only a very small (certainly not of the order of one biozone) amount of time. 


\section{Conclusions}

With the exception of the presence of the ostracod Frostiella groenvalliana in the Ludlow Bone Bed Member, all data (conodont, thelodont, lithological, sequence stratigraphical and carbon isotopic) are consistent with the Ludlow Bone Bed Member being of mid Ludfordian age and the Upper Whitcliffe Formation/Ludlow Bone Bed Member transition being a reflection of the major environmental changes associated with the mid Ludfordian positive CIE which we record here for the first time in the Ludlow area (and indeed from Britain) from Weir Quarry, with the commencement of the excursion high in the Upper Whitcliffe Formation.

\section{Acknowledgements}

We thank A. Butcher and B. Loveridge (University of Portsmouth) for their assistance in sample collection. Permission to visit Weir Quarry was granted by C. Lyons of Downton Estates Ltd and facilitated by C. Clayton of Natural England. M. Allbutt is thanked for drawing the first author's attention to Delbury Quarry. The paper benefited from the constructive reviews of P. Storch and M. Melchin. This work was partly supported by grants from the Grant Agency of the Czech Republic (205/09/0619 and 205/09/0703).

\section{References}

AldRIDGE, R.J. \& SCHÖNLAUB, H.-P. 1989. Conodonts, 274-279. In Holland, C.H. \& BassetT, M.G. (eds) A global standard for the Silurian System. National Museum of Wales, Cardiff.

Andrew, A.S., Hamilton, P.J., Mawson, R., Talent, J.A. \& WhITFORD, D.J. 1994. Isotopic correlation tools in the midPalaeozoic and their relation to extinction events. Australian Petroleum Exploration Association Journal 34, 268-277.

Barrick, J.E., Kleffner, M.A., Gibson, M.A., Peavey, F.N. \& KARLSSON, H.R. 2010. The mid-Ludfordian Lau Event and carbon isotope excursion (Ludlow, Silurian) in southern Laurentia - preliminary results. Bollettino della Società Paleontologica Italiana 49, 13-33.

Bassett, M.G., Lawson, J.D. \& White, D.E. 1982. The Downton Series as the fourth series of the Silurian System. Lethaia 15, 1-24. DOI 10.1111/j.1502-3931.1982.tb01114.x

CHERnS, L. 1982. Palaeokarst, tidal erosion surfaces and stromatolites in the Silurian Eke Formation of Gotland, Sweden. Sedimentology 29, 819-833.

DOI 10.1111/j.1365-3091.1982.tb00086.x

Corfield, R.M., Siveter, D.J., Cartlidge, J.E. \& McKerrow, W.S. 1992. Carbon isotope excursion near the Wenlock-Ludlow (Silurian) boundary in the Anglo-Welsh area. Geology 20, 371-374.

DOI 10.1130/0091-7613(1992)020<0371:CIENTW>2.3.CO;2

Corradini, C. 2009. Looking for a late Silurian Standard Conodont Zonation: still a long way to go. Rendiconti della Società Paleontologica Italiana 3, 273-274.

Corradini, C. \& Serpagli, E. 1999. A Silurian conodont biozonation from late Llandovery to end Přídolí in Sardinia (Italy). Bollettino della Società Paleontologica Italiana 37, 255-273.
Cramer, B.D., KlefFner, M.A. \& Saltzman, M.R. 2006. The late Wenlock Mulde positive carbon isotope $\left(\delta^{13} \mathrm{C}_{\text {carb }}\right)$ excursion in North America. GFF 128, 85-90. DOI 10.1080/11035890601282085

Cramer, B.D., Loydell, D.K., Samtleben, C., Munnecke, A., Kaljo, D., Männik, P., Martma, T., Jeppsson, L., Kleffner, M.A., Barrick, J. E., Johnson, C.A., Emsbo, P., JoAchimski, M.M., Bickert, T. \& SAltzMan, M.R. 2010. Testing the limits of Paleozoic chronostratigraphic correlation via high-resolution (<500 k.y.) integrated conodont, graptolite, and carbon isotope $\left(\delta^{13} \mathrm{C}_{\text {carb }}\right)$ biochemostratigraphy across the Llandovery-Wenlock (Silurian) boundary: is a unified Phanerozoic time scale achievable? Geological Society of America Bulletin 122, 1700-1716. DOI 10.1130/B26602.1

ERIKSSON, M.J. \& CALNER, M. 2008. A sequence stratigraphical model for the late Ludfordian (Silurian) of Gotland, Sweden: implications for timing between changes in sea level, palaeoecology, and the global carbon cycle. Facies 54, 253-276. DOI 10.1007/s10347-007-0128-y

GRAHN, Y. 1996. Upper Silurian (upper Wenlock-lower Pridoli) Chitinozoa and biostratigraphy of Skåne, southern Sweden. GFF 118, 237-250. DOI 10.1080/11035899609546259

Holland, C.H., Lawson, J.D. \& Walmsley, V.G. 1963. The Silurian rocks of the Ludlow district, Shropshire. Bulletin of the British Museum (Natural History) Geology 8, 95-171, pls 1-7.

JAGLIN, J.C. \& PARIS, F. 2002. Biostratigraphy, biodiversity and palaeogeography of late Silurian chitinozoans from A1-61 borehole (north-western Libya). Review of Palaeobotany and Palynology 118, 335-358.

DOI 10.1016/S0034-6667(01)00122-1

Jeppsson, L. 2005. Conodont-based revisions of the late Ludfordian on Gotland, Sweden. GFF 127, 273-282. DOI 10.1080/11035890501274273

Jeppsson, L. \& AldRidge, R.J. 2000. Ludlow (late Silurian) oceanic episodes and events. Journal of the Geological Society, London 157, 1137-1148. DOI 10.1144/jgs.157.6.1137

Jeppsson, L., Eriksson, M.E. \& Calner, M. 2006. A latest Llandovery to latest Ludlow high-resolution biostratigraphy based on the Silurian of Gotland - a summary. GFF 128, 109-114. DOI 10.1080/11035890601282109

Jeppsson, L., Talent, J.A., Mawson, R., Simpson, A.J., Andrew, A., Calner, M., Whitford, D., Trotter, J.A., SAndström, O. \& CALDON, H.J. 2007. High-resolution late Silurian correlations between Gotland, Sweden, and the Broken River region NE Australia: lithologies, conodonts and isotopes. Palaeogeography, Palaeoclimatology, Palaeoecology 245, 115-137. DOI 10.1016/j.palaeo.2006.02.032

JePPSSON, L., VIIRA, V. \& MÄNNIK, P. 1994. Silurian conodontbased correlations between Gotland (Sweden) and Saaremaa (Estonia). Geological Magazine 131, 201-218.

DOI 10.1017/S0016756800010736

Johnson, M.E. 1996. Stable cratonic sequences and a standard for Silurian eustasy. Geological Society of America Special Paper 306, 203-211.

Kaljo, D., KiIPLi, T. \& Martma, T. 1997. Carbon isotope event markers through the Wenlock-Pridoli sequence at Ohesaare (Estonia) and Priekule (Latvia). Palaeogeography, Palaeoclimatology, Palaeoecology 132, 211-223. DOI 10.1016/S0031-0182(97)00065-5

Kaljo, D., KiIPli, T. \& Martma, T. 1998. Correlation of carbon isotope events and environmental cyclicity in the East Baltic Silurian. New York State Museum Bulletin 491, 297-312. 
Kaljo, D. \& Martma, T. 2006. Application of carbon isotope stratigraphy to dating Baltic Silurian rocks. GFF 128, 123-129. DOI 10.1080/11035890601282123

Koren', T.N. \& WALliser, O.H. 1998. Stratigraphical ties between late Silurian graptolites and conodonts. Temas Geológico-Mineros Instituto Tecnológico Geominero de España $23,248-251$.

KŘiž, J., Jaeger, H., Paris, F. \& Schönlaub, H.P. 1986. Přídolí the fourth subdivision of the Silurian. Jahrbuch der Geologischen Bundesanstalt 129, 291-360.

LAUFELD, S. 1974. Silurian Chitinozoa from Gotland. Fossils and Strata 5, 1-130.

Lehnert, O., Frýda, J., Buggisch, W., Munnecke, A., Nützel, A., KŘiž, J. \& MANDA, S. 2007. $\delta^{13} \mathrm{C}$ records across the late Silurian Lau Event: new data from middle palaeolatitudes of northern peri-Gondwana. Palaeogeography, Palaeoclimatology, Palaeoecology 245, 227-244.

DOI 10.1016/j.palaeo.2006.02.022

LOYDELL, D.K. 2007. Early Silurian positive $\delta^{13} \mathrm{C}$ excursions and their relationship to glaciations, sea-level changes and extinction events. Geological Journal 42, 531-546.

DOI $10.1002 / \mathrm{gj} .1090$

LOYDELL, D.K. In press. Graptolite biozone correlation charts. Geological Magazine.

LOYDELL, D.K. \& FRÝDA, J. 2007. Carbon isotope stratigraphy of the upper Telychian and lower Sheinwoodian (Llandovery-Wenlock, Silurian) of the Banwy River section, Wales. Geological Magazine 144, 1015-1019.

DOI 10.1017/S0016756807003895

Manda, Š., Štorch, P., Slavík, L., FrÝda, J., Křiž, J. \& TASÁRYOVÁ, Z. In press. The graptolite, conodont and sedimentary record through the late Ludlow Kozlowskii Event (Silurian) in the shale-dominated succession of Bohemia. Geological Magazine.

Märss, T. \& Miller, C.G. 2004. Thelodonts and distribution of associated conodonts from the Llandovery-lowermost Lochkovian of the Welsh Borderland. Palaeontology 47, 1211-1265. DOI 10.1111/j.0031-0239.2004.00409.x

Melchin, M.J. \& Holmden, C. 2006. Carbon isotope chemostratigraphy of the Llandovery in Arctic Canada: implications for global correlation and sea-level change. GFF 128, 173-180. DOI 10.1080/11035890601282173

Melchin, M.J., KoreN', T.N. \& Štorch, P. 1998. Global diversity and survivorship patterns of Silurian graptolites. New York State Museum Bulletin 491, 165-182.

MiLLER, C.G. 1995. Ostracode and conodont distribution across the Ludlow/Přídolí boundary of Wales and the Welsh borderland. Palaeontology 38, 341-384.

MillER, C.G. \& MÄrsS, T. 1999. A conodont, thelodont and acanthodian fauna from the lower Př́dolí (Silurian) of the Much Wenlock area, Shropshire. Palaeontology 42, 691-714. DOI 10.1111/1475-4983.00093

Miller, C.G., Sutherland, S.J.E. \& Dorning, K.J. 1997. Late Silurian (Ludlow-Přídolí) microfossils and sedimentation in the Welsh Basin near Clun, Shropshire. Geological Journal 32, 69-83.

DOI 10.1002/(SICI)1099-1034(199703)32:1<69::AID-GJ734> 3.0.CO;2-Q

Munnecke, A., SAmtleben, C. \& Bickert, T. 2003. The Ireviken Event in the lower Silurian of Gotland, Sweden - relation to similar Palaeozoic and Proterozoic events. Palaeogeography, Palaeoclimatology, Palaeoecology 195, 99-124. DOI 10.1016/S0031-0182(03)00304-3
Nestor, V. 2009. Biostratigraphy of the Ludlow chitinozoans from East Baltic drill cores. Estonian Journal of Earth Sciences $58,170-184$.

DOI 10.3176/earth.2009.3.02

Noble, P.J., Zimmerman, M.K., Holmden, C. \& LenZ, A.C. 2005. Early Silurian (Wenlockian) $\delta^{13} \mathrm{C}$ profiles from the Cape Phillips Formation, Arctic Canada and their relation to biotic events. Canadian Journal of Earth Sciences 42, 1419-1430. DOI 10.1139/e05-055

PARIS, F. \& KŘíž, J. 1984. Nouvelles espéces de Chitinozoaires à la limite Ludlow/Pridoli en Tchécoslovaquie. Review of Palaeobotany and Palynology 43, 155-177.

DOI 10.1016/0034-6667(84)90031-9

Richardson, J.B. \& RASUL, S.M. 1990. Palynofacies in a late Silurian regressive sequence in the Welsh Borderland and Wales. Journal of the Geological Society, London 147, 675-686. DOI 10.1144/gsjgs.147.4.0675

Siveter, D.J., Owens, R.M. \& Thomas, A.T. 1989. Silurian field excursions: a geotraverse across Wales and the Welsh Borderland. 133 pp. National Museum of Wales, Cardiff.

Slavík, L., KŘíž, J. \& Carls, P. 2010. Reflection of the midLudfordian Lau Event in conodont faunas of Bohemia. Bulletin of Geosciences 85, 395-414.

DOI 10.3140/bull.geosci.1204

SMith, R.D.A. \& Ainsworth, R.B. 1989. Hummocky cross-stratification in the Downton of the Welsh borderland. Journal of the Geological Society, London 146, 897-900. DOI 10.1144/gsjgs.146.6.0897

Stricanne, L., Munnecke, A. \& Pross, J. 2006. Assessing mechanisms of environmental change: palynological signals across the late Ludlow (Silurian) positive isotope excursion $\left(\delta^{13} \mathrm{C}\right.$, $\left.\delta^{18} \mathrm{O}\right)$ on Gotland, Sweden. Palaeogeography, Palaeoclimatology, Palaeoecology 230, 1-31.

DOI 10.1016/j.palaeo.2005.07.003

SuTHERLAND, S.J.E. 1994. Ludlow chitinozoans from the type area and adjacent regions. Monograph of the Palaeontographical Society 148(594), 1-104, pls 1-18.

URBANEK, A. 1993. Biotic crises in the history of upper Silurian graptoloids: a palaeobiological model. Historical Biology 7, 29-50. DOI 10.1080/10292389309380442

URBANEK, A. \& TELLER, L. 1997. Graptolites and stratigraphy of the Wenlock and Ludlow Series in the East European Platform. Palaeontologia Polonica 56, 23-57.

Verniers, J., Nestor, V., Paris, F., Dufka, P., Sutherland, S. \& VAN Grootel, G. 1995. A global Chitinozoa biozonation for the Silurian. Geological Magazine 132, 651-666. DOI 10.1017/S0016756800018896

ViIRA, V. \& AldRidge, R.J. 1998. Upper Wenlock to lower Přídolí (Silurian) conodont biostratigraphy of Saaremaa, Estonia, and a correlation with Britain. Journal of Micropalaeontology 17, 33-50. DOI 10.1144/jm.17.1.33

Wigforss-Lange, J. 1999. Carbon isotope ${ }^{13} \mathrm{C}$ enrichment in Upper Silurian (Whitcliffian) marine calcareous rocks in Scania, Sweden. GFF 121, 273-279. DOI 10.1080/11035899901214273

Woodcock, N.H., Awan, A., Johnson, T.E., Mackie, A.H. \& SмITH, R.D.A. 1988. Acadian tectonics of Wales during Avalonia/Laurentia convergence. Tectonics 7, 483-495. DOI 10.1029/TC007i003p00483

Wrona, R. 1980. Upper Silurian-Lower Devonian Chitinozoa from the subsurface of southeastern Poland. Palaeontologia Polonica 41, 103-165. 